\title{
Leachates of Thermally Modified Pine (Pinus sylvestris L.) Wood
}

\author{
Anete Meija-Feldmane* \\ Latvian State Institute of Wood Chemistry, Dzērbenes str. 27, LV-1006, Latvia
}

\begin{abstract}
During the last decades, thermally modified wood has become an object of interest among the wood scientists as an environmentally friendly material, because nowadays environmental aspects of materials have become more and more significant. Leaching is one of the processes that occurs in outdoor use. The aim of this study was to evaluate concentration of potentially hazardous substances in leachates of thermally modified pine wood. Scots pine (Pinus sylvestris L.) wood was thermally modified using Wood Treatment Technology (WTT) company device at $170{ }^{\circ} \mathrm{C}$ for 1 hour (TMP170/1) and at $160{ }^{\circ} \mathrm{C}$ for 3 hours (TMP160/3) and the mass loss was calculated. Material preparation and leaching procedure was made according to standard LVS EN 84:2000. In obtained leachates, the content of sugars, acetic acid, furfural and tannic acid were determined. Results showed that the total wood mass loss was $7.1 \pm 1.4 \%(n=20)$ for TMP170/1 and $4.0 \pm 1.6 \%(n=20)$ for TMP160/3. The initial leaching velocity differs between both modes and is higher for TMP160/3. The velocity decreases exponentially with immersion time and reaches plateau after $7^{\text {th }}$ ( 5 days) immersion, but leaching still continues after the $9^{\text {th }}$ immersion (14 days). The main components in leachates were tannic acid and pentoses. Among all studied compounds furfural is the hardest leachable one. Thermally modified wood treated at TMP170/1 is more environmentally friendly due to less water leachable substances. It is worth looking forward by investigating volatile organic compounds emissions in the air as it also could give high impact on human health.
\end{abstract}

Key words: Thermally modified wood, leachates, furfural, softwood.

\section{Introduction}

Thermal modification of wood has been investigated during the last decades as an alternative approach to obtain bio-durable wood (International ThermoWood Association, 2003). The properties of material both mechanical (Esteves \& Pereira, 2008; Korkut, Akgül, \& Dündar, 2008; Srinivas \& Pandey, 2012) and decay resistance (Boonstra et al., 2006) have been widely investigated. Relatively fewer researches are devoted to the environmental impact of this material (Kamdem, Pizzi, \& Triboulot, 2000; Peters, Fischer, \& Fischer, 2008; Vetter et al., 2008). As the only chemical agent used in this treatment is water, it is considered to be an environmentally friendly method (Finnish ThermoWood Association, 2008). Nowadays evaluation of material impact on environment life cycle assessment has become more and more significant (European Commission, 2014). This system approach requires a lot of input data, and it is considered to be improved whenever new data appears (LVS EN ISO 14044: 2006). Life cycle assessment of thermally treated and untreated maritime pine boards (Ferreira et al., 2014) shows that thermally treated wood has a high weight of impact on human health $(100 \%)$; therefore, it is essential to provide additional data about its service life.

One of the processes in material usage outdoors is leaching. It is also a standardized procedure for accelerated ageing (LVS EN 84:2000) and is commonly used for impregnated wood testing. Leachates of thermally modified wood consist mainly of wood constituents degradation products. Total mass loss is the one of the main characteristics of degradation degree in thermal treatment; it depends on the wood species, heating medium, temperature and treatment time, among which the temperature has the most influence. Hemicelluloses are the most easily degradable wood components and form hexoses and pentoses (sugars) when exposed to high temperatures, which in turn degrade further forming furfural from pentoses (Esteves \& Pereira, 2008). The acetic acid is formed during the thermolysis of the acetyl radicals linked to xylose in xylans. Leachates contain not only the mentioned wood thermal degradation products, but also extractives. Tannins belong to water-soluble group of extractives - large polyphenol compounds containing hydroxyl groups that bound to wood macromolecules.

The aim of this study was to compare pine wood, modified in two different regimes in relevance of leaching by determining the total mass loss during the thermal treatment, as well as detecting concentration of hazardous substances in leachates of thermally modified pine wood.

\footnotetext{
* Corresponding Author's email:

a.meija.feldmane@gmail.com
} 


\section{Materials and Methods}

The experiments were carried out in the Laboratory of Wood Biodegradation and Protection of the Latvia State Institute of Wood Chemistry.

Thermal modification. Scots pine (Pinus sylvestris L.) was chosen for this study as it is the most common wood species in Latvia. Pine wood was thermally modified using Wood Treatment Technology (WTT) device. The dimensions of the wood boards before the thermal treatment were $1000 \times 100 \times 25 \mathrm{~mm}$. The treatment was conducted in a water vapour medium under elevated pressure $(0.6 \mathrm{MPa})$ at $170{ }^{\circ} \mathrm{C}$ temperature for $1 \mathrm{~h}(\mathrm{TMP} 170 / 1)$ and other set of samples at $160{ }^{\circ} \mathrm{C}$ temperature for $3 \mathrm{~h}$ (TMP160/3). Afterwards, modified boards were conditioned at $20{ }^{\circ} \mathrm{C}$ and $65 \%$ relative humidity, measured and weighted in order to calculate mass loss.

Leaching. Material preparation and leaching procedure was made according to standard LVS EN 84:2000. The leaching procedure consisted of an initial impregnation with distilled water under 4 $\mathrm{kPa}$ vacuum for $20 \mathrm{~min}$. The water was subsequently replaced $2 \mathrm{~h}$ after the impregnation, continuing at $24 \mathrm{~h}$ and $48 \mathrm{~h}$, and another seven times in the next 12 days at intervals of not less than 1 day and not more than 3 days. The leachates were collected, their volume measured, and part of them stored in $5^{\circ} \mathrm{C}$.

Sugar analysis. For sugar analysis $0.1 \mathrm{~mL}$ of $10 \%$ sulphuric acid and $1 \mathrm{~mL} 0.2 \mathrm{M}$ sodium periodate solution were added to approximately $10 \mathrm{~g}$ of leachate after that sample was kept in $40{ }^{\circ} \mathrm{C}$ for $5 \mathrm{~h}$, and then $5 \mathrm{~mL}$ of fresh $10 \%$ ammonium molibdate solution was added. Fifteen minutes later $1 \mathrm{~mL}$ of glacial acetic acid and $1 \mathrm{~mL}$ of $10 \%$ potassium iodate solution were added. After 15 minutes samples were titrated with $0.1 \mathrm{M}$ standardized sodium thiosulphate (against potassium dihromate) solution. The results were recalculated to the relative mass of hexoses or pentoses $(\mathrm{w} \%)$. In the described method, the following reactions (Eq. 1, Eq. 2) take place:

$$
\begin{aligned}
& \mathrm{C}_{6} \mathrm{H}_{12} \mathrm{O}_{6}+5 \mathrm{NaIO}_{4} \rightarrow \\
& \rightarrow 5 \mathrm{HCOOH}+\mathrm{H}_{2} \mathrm{CO}+5 \mathrm{NaIO}_{3} \\
& \mathrm{C}_{5} \mathrm{H}_{10} \mathrm{O}_{5}+4 \mathrm{NaIO}_{4} \rightarrow \\
& \rightarrow 4 \mathrm{HCOOH}+\mathrm{H}_{2} \mathrm{CO}+4 \mathrm{NaIO}_{3}
\end{aligned}
$$

Tannin analysis. Content of tannins in leachates was obtained by measuring absorption of samples at $280 \mathrm{~nm}$ and plotting the results against calibration curve of tannic acid. Measurements were made with UV-VIS Spectrometer Genesys ${ }^{\mathrm{TM}} 10$.

Acid analysis. Content of short chain carboxylic acids was determined by titrating the acetic acid within the leachates with standardized $0.1 M$ potassium hydroxide solution (standard - potassium hydrogenpfhtalate).

Aldehyde analysis. In order to find out approximate content of aldehydes, $5 \mathrm{~mL}$ of $0.5 \mathrm{M}$ hydroksylamine hydrochloride solution were added to $10 \mathrm{~g}$ of sample. After $2.5 \mathrm{~h} 20 \mathrm{~mL}$ propanol-2 were added and three parallel samples were titrated with standardized $0.1 M$ potassium hydroxide solution (standard - potassium hydrogenphtalate). The following reaction (Eq. 3) occurs:

$$
\begin{aligned}
& \mathrm{RCHO}+\mathrm{H}_{2} \mathrm{NOH} \cdot \mathrm{HCl} \rightarrow \\
& \rightarrow \mathrm{RCHNOH}+\mathrm{HCl}+\mathrm{H}_{2} \mathrm{O}
\end{aligned}
$$

The results were expressed as relative mass of furfural in sample.

The results were processed by mathematical and statistical methods with software Microsoft EXCEL 2010. Mean values and standard deviations of the samples were calculated.

\section{Results and Discussion}

This study also reveals that temperature is the most significant factor in thermal modification although treatment time at $160{ }^{\circ} \mathrm{C}$ was three times longer $(3 \mathrm{~h})$ than in $170{ }^{\circ} \mathrm{C}(1 \mathrm{~h})$ mass loss at lower temperature $(4.0 \pm 1.6 \%, \mathrm{n}=20)$ was almost two times smaller than in higher temperature $(7.1 \pm 1.4 \%, \mathrm{n}=20)$. The standard deviations are relatively high and only slightly differ between both treatments, more likely due to the variety of the pine wood itself. MetsäKortelainen (2011) in ThermoWood $\AA$ process has obtained that at $170{ }^{\circ} \mathrm{C} 3 \mathrm{~h}$ modified pine sapwood has a mass loss of about $2 \%$, which is 3 times less than results obtained in this study. It is more likely due to the evaluate pressure in thermal modification used in this study.

Results show that after 14 days the total amount of leached substances was $21 \%$ higher from pine wood thermally modified at $160{ }^{\circ} \mathrm{C}$ (Table 1 ) than from pine wood thermally modified at $170{ }^{\circ} \mathrm{C}$ (Table 2). Sugars were the main components (38\%) leached from TMP160/3 while for TMP170/1 sugars were only $26 \%$ due to further degradation of sugars forming carboxylic acids and aldehydes. The main component leached from TMP170/1 was the tannic acid (43\%). Also, in the leachates of TMP160/3 (35\%) the content of tannic acid was high.

Results of Graf, Wagner, Begander, Trinkaus, \& Boechzelt (2005) showed that the main components of leachates include acetic acid, furfural and furfural derivatives ( $80 \%$ from almost 100 compounds). In this study acetic acid constitutes 15\% (TMP160/3) and 20\% (TMP170/1) of total leached and identified 
Content of organic substances in leachates of pine wood, thermally modified at $160{ }^{\circ} \mathrm{C}$ for $3 \mathrm{~h}$, $\mathrm{mg}$ of leached substance per $\mathrm{g}$ absolute dry sample

\begin{tabular}{|c|c|c|c|c|c|c|c|c|c|}
\hline $\begin{array}{c}\text { No. of } \\
\text { immersion }\end{array}$ & Time, $\mathrm{h}$ & $\begin{array}{c}\text { Acetic } \\
\text { acid }\end{array}$ & Stdev. & Furfural & Stdev. & Tannic acid & Stdev. & Sugars & Stdev. \\
\hline 1 & 4 & 0.40 & 0.006 & 0.24 & 0.097 & 1.12 & 0.0002 & 0.92 & 0.01 \\
\hline 2 & 24 & 2.08 & 0.009 & 1.39 & 0.098 & 4.35 & 0.0041 & 4.38 & 0.09 \\
\hline 3 & 27 & 1.46 & 0.000 & 1.18 & 0.136 & 2.99 & 0.0045 & 3.37 & 0.16 \\
\hline 4 & 48 & 1.74 & 0.003 & 1.55 & 0.045 & 3.91 & 0.0018 & 4.66 & 0.10 \\
\hline 5 & 28 & 0.67 & 0.010 & 0.73 & 0.064 & 1.87 & 0.0109 & 1.79 & 0.05 \\
\hline 6 & 43 & 0.55 & 0.002 & 0.73 & 0.036 & 1.70 & 0.0018 & 1.85 & 0.06 \\
\hline 7 & 52 & 0.31 & 0.012 & 0.27 & 0.182 & 0.86 & 0.0055 & 1.08 & 0.01 \\
\hline 8 & 48 & 0.32 & 0.090 & 0.27 & 0.180 & 0.80 & 0.0018 & 1.05 & 0.03 \\
\hline 9 & 62 & 0.25 & 0.008 & 0.36 & 0.004 & 0.89 & 0.0008 & 1.09 & 0.01 \\
\hline & Total & 7.8 & & 6.7 & & 18.5 & & 20.2 & \\
\hline
\end{tabular}

Table 2

Content of organic substances in leachates of pine wood, thermally modified at $170^{\circ} \mathrm{C}$ for $1 \mathrm{~h}$, mg of leached substance per $\mathrm{g}$ absolute dry sample

\begin{tabular}{|c|c|c|c|c|c|c|c|c|c|}
\hline $\begin{array}{c}\text { No. of } \\
\text { immersion }\end{array}$ & Time, h & Acetic acid & Stdev. & Furfural & Stdev. & Tannic acid & Stdev. & Sugars & Stdev. \\
\hline 1 & 4 & 0.53 & 0.005 & 0.16 & 0.005 & 1.28 & 0.0004 & 0.60 & 0.01 \\
\hline 2 & 24 & 1.96 & 0.031 & 0.46 & 0.231 & 3.63 & 0.0015 & 2.14 & 0.08 \\
\hline 3 & 27 & 1.63 & 0.002 & 0.95 & 0.130 & 2.97 & 0.0104 & 1.75 & 0.03 \\
\hline 4 & 48 & 1.96 & 0.061 & 1.12 & 0.173 & 3.71 & 0.0006 & 2.48 & 0.06 \\
\hline 5 & 28 & 0.74 & 0.009 & 0.61 & 0.035 & 1.74 & 0.0004 & 0.96 & 0.04 \\
\hline 6 & 43 & 0.66 & 0.007 & 0.61 & 0.259 & 1.79 & 0.0017 & 1.08 & 0.02 \\
\hline 7 & 52 & 0.30 & 0.006 & 0.43 & 0.112 & 0.80 & 0.0012 & 0.53 & 0.01 \\
\hline 8 & 48 & 0.35 & 0.017 & 0.26 & 0.095 & 1.12 & 0.0005 & 0.73 & 0.02 \\
\hline 9 & 62 & 0.27 & 0.004 & 0.34 & 0.026 & 1.00 & 0.0017 & 0.62 & 0.00 \\
\hline & Total & 8.4 & & 4.9 & & 18.0 & & 10.9 & \\
\hline
\end{tabular}

amount of substances but furfural $13 \%$ and $12 \%$ respectively. This discrepancy can be explained by the sensitivity of used methods. Graf, Karlsson and colleagues had used gas chromatography-mass spectrometry and identified single compounds while in this study, results represent a group of substances with similar composition - pentoses represent sugar content; acetic acid represents content of short chain carboxylic acids; furfural represents the content of aldehydes and tannic acid represents the content of aromatic phenolic compounds. Karlsson, Torniainen, Dagbro, Granlund, \& Moren (2012) state that under saturated steam at $170{ }^{\circ} \mathrm{C}$ thermally modified pine wood leaches $0.586 \%$ of dry mass 5-(hydroxymethyl) furfural and $0.029 \%$ furfural, which is in total $0.615 \%$ furan compounds of dry mass. Recalculating results in this research, obtained values are $0.672 \%$ for TMP160/3 and $0.494 \%$ for TMP170/1. This could be explained due to the furfural leaching during thermal modification in WTT process or due to furfural polymerization with lignin destruction products, forming resins.

It could be also relevant to prolong the experiment because after the $9^{\text {th }}$ immersion ( 14 days) curves of total furfural content have not reached plateau (Figure 1). The same pattern can be observed for curves of tannic acid, acetic acid and sugars.

The sugar leaching velocity decreases exponentially depending on water immersion time (Figue 2). The velocity of leaching of the sugars from pine wood, thermally modified at TMP160/3 is the highest at the beginning $\left(0.32 \mathrm{mg} \mathrm{h}^{-1} \mathrm{~g}^{-1}\right)$, and 


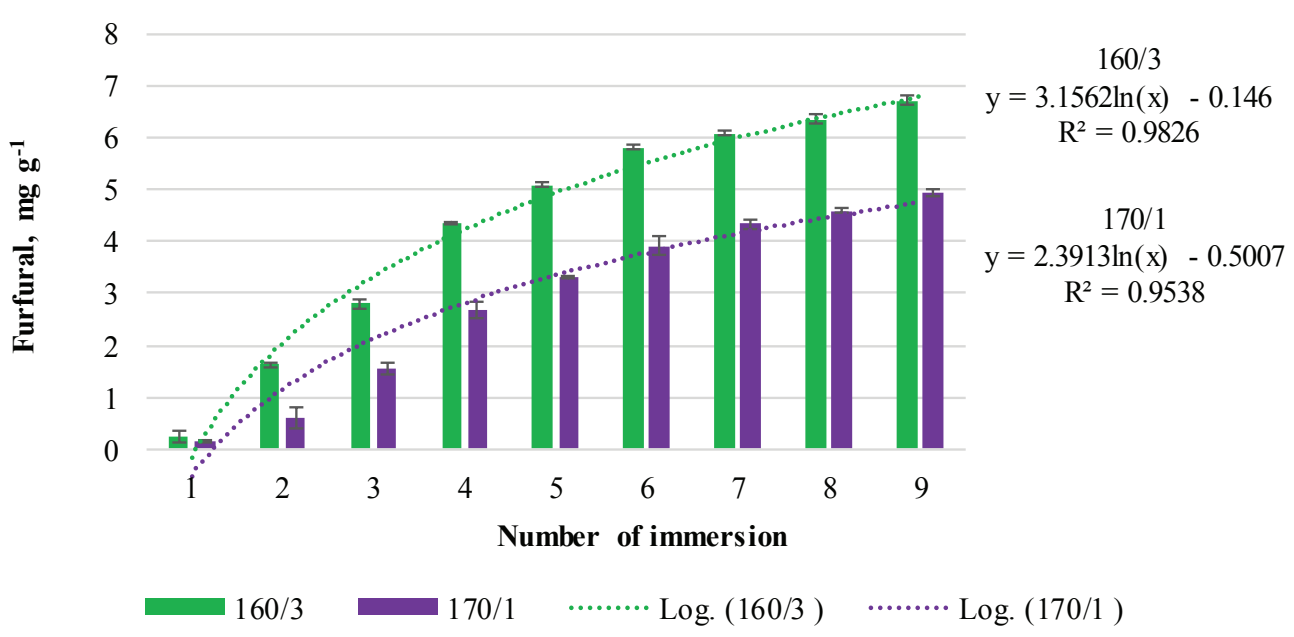

Figure 1. Total content of furfural in leachates of thermally modified pine wood treated in two different modes depending on the number of immersions.

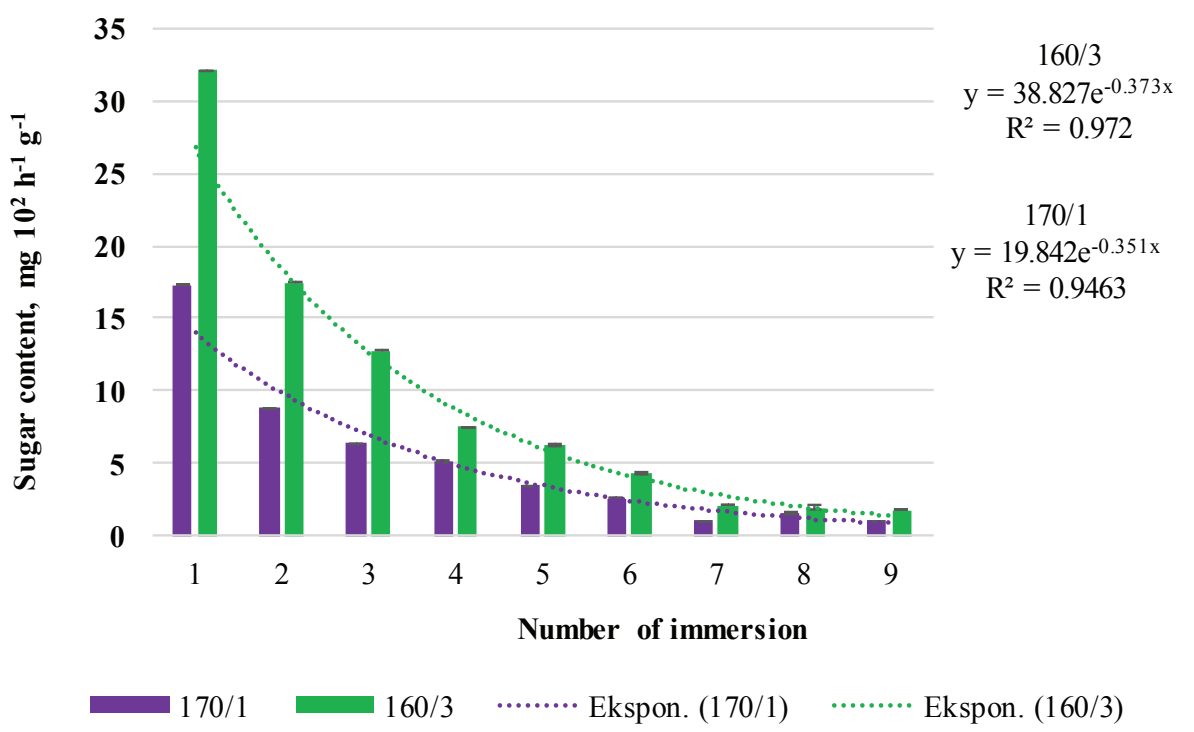

Figure 2. Sugar leaching velocity of thermally modified pine wood treated in two different modes depending on the number of immersions.

decreases with repeated number of water replacement and after the $7^{\text {th }}$ immersion reaches plateau at 0.02 $\mathrm{mg} \mathrm{h}^{-1} \mathrm{~g}^{-1}$. For thermally modified wood treated at TMP170/1, initial sugar leaching velocity is almost twice as slow $\left(0.17 \mathrm{mg} \mathrm{h}^{-1} \mathrm{~g}^{-1}\right)$ and likewise it reaches plateau after the $7^{\text {th }}$ immersion at $0.02 \mathrm{mg} \mathrm{h}^{-1} \mathrm{~g}^{-1}$.

The same pattern can be observed with furfural leaching - initial velocity rate for TMP160/3 treated wood is $0.08 \mathrm{mg} \mathrm{h}^{-1} \mathrm{~g}^{-1}$ while for TMP170/1 only 0.04 $\mathrm{mg} \mathrm{h}^{-1} \mathrm{~g}^{-1}$, reaching plateau after the $7^{\text {th }}$ immersion at $0.01 \mathrm{mg} \mathrm{h}^{-1} \mathrm{~g}^{-1}$. Tannic acid and acetic acid substances have similar leaching velocity curves to those of the previously described - sugars and furfural although there is no significant difference between initial velocities for wood modified at TMP170/1 and TMP160/3. They are 0.37 and $0.38 \mathrm{mg} \mathrm{h}^{-1} \mathrm{~g}^{-1}$ for tannic acid, 0.15 and $0.14 \mathrm{mg} \mathrm{h}^{-1} \mathrm{~g}^{-1}$ for acetic acid with plateau at 0.015 and $0.006 \mathrm{mg} \mathrm{h}^{-1} \mathrm{~g}^{-1}$ respectively.

Unfortunately, by the methods used it was not possible to distinquish hexoses and pentoses. Results of Karlsson, Torniainen, Dagbro, Granlund, \& Moren (2012) showed that leachates of pine wood thermally modified for 3 hours at $170{ }^{\circ} \mathrm{C}$ contain $37 \%$ more hexoses than pentoses. As this result is obtained with gas chromatography-flame ionization detector, it is more likely that difference in sugar amounts of leachate exist, but are above sensitivity of approach used in this study. 


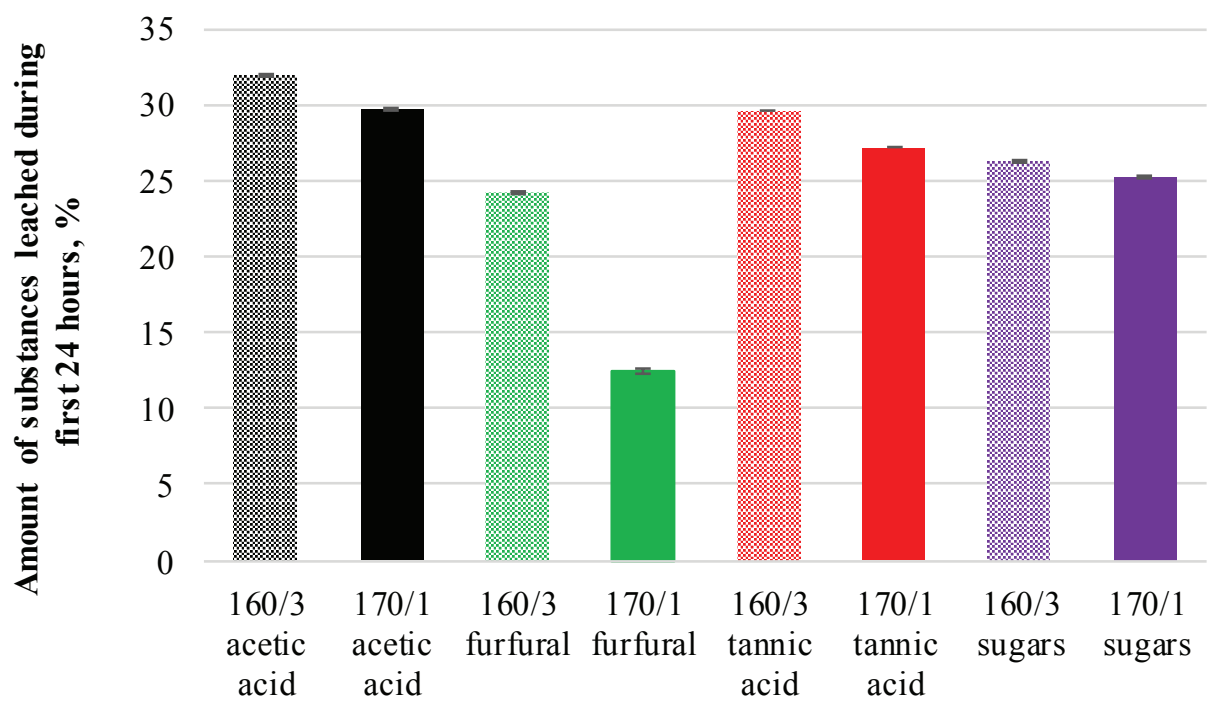

Figure 3. Amount of substances leached during the first 24 hours as percentage of total leached amount.

Comparing percentage of the total amount of all studied constituents of leachates after the first 24 hours of experiment, reveal that the acetic acid leaches most easily, followed by tannic acid and sugars (Figure 3). Furfural is more difficult to leach.

All studied compounds leach more easily from pine wood treated at TMP160/3 and in greater total amount than from pine wood modified at TMP170/1. It is more likely due to wood cell wall shrinkage after thermal treatment that increases with temperature. In addition, due to the thermal degradation of wood components, the content of hydroxyl groups decreases leading to increased hydrophobity and more difficult wettability. According to obtained results of wood mass loss during the thermal treatment, degradation process in TMP170/1 occurs at greater degree than in TMP160/3 modified wood, thereby reducing the amount of substances accessible to leach. Mass loss in TMP170/1 is $7.5 \pm 1.4$, which is comparable with results obtained in other studies $-7.3 \%$ (Esteves et al., 2007); 6.9\% (Brito et al., 2008), whereas mass loss in TMP160/3 is $4.0 \pm 1.6$.

\section{Conclusions}

As expected, the leaching velocity of investigated substances - acetic acid, furfural, tannic acid and sugars - decreases exponentially with repeated immersions. Although the velocity plateau is reached after the $7^{\text {th }}$ immersion ( 9 days), it is worth to prolong the experiment because after the $9^{\text {th }}$ immersion $(14$ days) the investigated substances still continue to leach. Pine wood thermally modified for 1 hour at $170{ }^{\circ} \mathrm{C}$ in WTT is more environmentally friendly due to less in water leachable substances. Hereafter, it is worth looking forward by investigating volatile organic compounds emissions in the air as it also could give high impact on human health.

\section{References}

1. Boonstra, M. J., Acker, J., Kegel, E., \& Stevens, M. (2006). Optimisation of a twostage heat treatment process: durability aspects. Wood Science and Technology, 41(1), 31-57. Retrieved August 15, 2014, from Springerlink database on the World Wide Web: http://link. springer.com/10.1007/s00226-006-0087-4. DOI:10.1007/s00226-006-0087-4.

2. Brito, J.O., Silva, F. G., Leão, M. M., \& Almeida, G. (2008). Chemical composition changes in eucalyptus and pinus woods submitted to heat treatment. Bioresource Technology, 99, 85458548. Retrieved May 27, 2015, from PubMed database on the World Wide Web: http://www. ncbi.nlm.nih.gov/pubmed/18586488. DOI: 10.1016/j.biortech.2008.03.069.

3. Esteves, B., Marques, A. V., Domingos, I., \& Pereira, H. (2007). Influence of steam heating on the properties of pine (Pinus pinaster) and eucalypt (Eucalyptys globulus) wood. Wood Science and Technology, 41, 193-207. Retrieved August 15, 2014, from Springerlink database on the World Wide Web: http://link. springer.com/10.1007/s00226-006-0099-0. DOI:10.1007/s00226-006-0099-0.

4. Esteves, B., \& Pereira, H. (2008). Wood modification by heat treatment: a review. BioResources, 4(1), 370-404. Retrieved August 24, 2014, from BioResources 
database on the World Wide Web: http://ojs. cnr.ncsu.edu/index.php/BioRes/article/view/ BioRes_04_1_\%23\%23\%23\%23_Esteves_P Wood_Mod_Heat_Treatment. DÖI:10.15376/ biores.4.1.370-40 $\overline{4}$.

5. European Commission. (2014, August). European Platform on Life Cycle Assessment (LCA). Retrieved August 24, 2014, from http:// ec.europa.eu/environment/ipp/lca.htm.

6. Ferreira, J., Esteves, B., Nunes, L. \& Domingos, I. (2014). Life cycle assessment of thermally treated and untreated maritime pine boards: a Portuguese case study. In European Conference on Wood Modification, 10-12 March 2014. Lisbon, Portugal: Laboratório Nacional de Engenharia Civil.

7. Finnish ThermoWood Association. (2008).

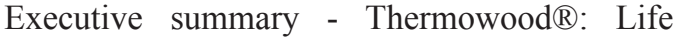
cycle assessment. Espoo: Publishing House Koivuniemi Ltd.

8. Graf, N., Wagner, S., Begander, U., Trinkaus, P. \& Boechzelt, H. (2005). Gaseous emissions from thermal wood modification as a source for fine chemicals recovery. Graz: Joanneum Research $\mathrm{GmbH}$.

9. International ThermoWood Association. (2003). Handbook. Helsinki, Finnland: Wood Focus Oy.

10. Kamdem, D.P., Pizzi, A. \& Triboulot, M.C. (2000). Heat-treated timber: potentially toxic byproducts presence and extent of wood cell wall degradation. Holz als Roh- und Werkstoff, 58(4), 253-257. Retrieved August 24, 2014, from Springerlink database on the World Wide Web: http://link.springer.com/10.1007/ s001070050420. DOI:10.1007/s001070050420.

11. Karlsson, O., Torniainen, P., Dagbro, O., Granlund, K. \& Moren, T. (2012). Presence of water-soluble compounds in thermally modified wood: carbohydrates and furfurals. BioResources, 7(3), 3679-3689. Retrieved August 24, 2014, from BioResources database on the World Wide Web: https://ojs.cnr. ncsu.edu/index.php/BioRes/article/view/ BioRes_07_3_3679_Karlsson_TDGM_Water Soluble_Cmpds_Thermal_Modified_Wood. DOI:10.15376/biores.7.3.3679-3689.

12. Korkut, S., Akgül, M. \& Dündar, T. (2008). The effects of heat treatment on some technological properties of Scots pine (Pinus sylvestris L.) wood. Bioresource Technology, 99(6), 1861-1868. Retrieved October 10, 2013, from PubMed database on the World Wide Web:http:// www.ncbi.nlm.nih.gov/pubmed/17482811. DOI:10.1016/j.biortech.2007.03.038.

13. LVS EN 84:2000. Wood preservatives Accelerated ageing of treated wood prior to biological testing - Leaching procedure. Riga: Latvian Standard.

14. LVS EN ISO 14044:2006. Environmental management - Life cycle assessment Requirements and guidelines. Riga.

15. Metsä-Kortelainen, S. (2011). Differences between sapwood and heartwood of thermally modified Norway spruce (Picea abies) and Scots pine (Pinus sylvestris) under water and decay exposure. Doctoral dissertation, Aalto university, Espoo, Finland. Retrieved May 26, 2015 from the World Wide Web: http:/www.vtt. fi/inf/pdf/publications/2011/P771.pdf.

16. Peters, J., Fischer, K., \& Fischer, S. (2008). Characterization of emissions of thermally modified wood and their reduction by chemical treatment. BioResources. 3(2), 491-52. Retrieved August 26, 2014, from BioResources database on the World Wide Web: http://ojs.cnr.ncsu.edu/index.php/BioRes/ article/view/BioRes_03_2_0491_Peters_FF_ Emissions Thermal_Wood. DOI:10.15376/ biores.3.2.491-502.

17. Srinivas, K. \& Pandey, K. K. (2012). Photodegradation of thermally modified wood. Journal of Photochemistry and Photobiology B: Biology, 117, 140-145. Retrieved May 28, 2014, from PubMed database on the World Wide Web: http://www.ncbi.nlm. nih.gov/pubmed/23123593. DOI:10.1016/j. jphotobiol.2012.09.03.

18. Vetter, L., Depraetere, G., Janssen, C., Stevens, M. \& Van Acker, J. (2008). Methodology to assess both the efficacy and ecotoxicology of preservative-treated and modified wood. Annals of Forest Science, 65(5), 504-504. Retrieved August 24, 2014, from Springerlink database on the World Wide Web: http://link.springer.com. DOI:10.1051/forest:2008030.

\section{Acknowledgements}

The author gratefully acknowledges the financial support by the Latvian State Research Programme 'Forest and earth entrails resources: research and sustainable utilization - new products and technologies' NatProd (2014-2017). 